\title{
THE KALAHARI GEMSBOK NATIONAL PARK : 1931-1981
}

\section{P. VAN WYK}

Department of Research and Information

National Parks Board of Trustees

P.O. Box 787

Pretoria

0001

\section{E. A. N. LE RICHE}

\author{
Kalahari Gemsbok National Park \\ Private Bag X5890 \\ Gemsbokpark \\ 8815
}

The history and development of the Kalahari Gemsbok National Park is inseparable from the well-known Le Riche family, although they were not directly involved in the establishment of the park. For this reason their history must form an integral part of this document. At about 1880, Christoffel, a son of the ancestor (Louis), trekked in a northwesterly direction with his three transport wagons, his young wife, three small children and a number of servants. After suffering many hardships in the thirstland of the Kalahari, they eventually arrived at Rietfontein to the south of the present park on the South West African border. A mission post under the control of the Rhenish missionary, Father Pabst, existed there at the time, and Christoffel established a trading post. A son, Joseph, or Joep, who later played an important role in the park, was born there in 1903.

After the First World War the area between the Auob and Nossob Rivers had already been earmarked as a Coloured area, and the only inhabitants at that stage were a few settlers on privately owned farms such as Kameelsleep, Kij Kij and -Twee Rivieren, and the so-called "borehole guards" along the Auob. The latter were present in the area because the Union government sank several boreholes in the Auob and Kuruman Rivers at the outbreak of war (1914) as a precautionary measure against a possible invasion into South West Africa, or German South West, as it was then called. Windmills were erected and guards were appointed to protect this government property. Primitive lodgings were provided - some lived in tents, while others enjoyed the luxury of "hartbeeshuisies" (wattle-and-daub huts), the ruins of which are still to be seen on the banks of the Auob. The invasion never followed this route, however, but was made along the Kuruman River and via Rietfontein.

On the Botswana side of the Nossob there were a number of Coloured hamlets stretching from the confluence to almost as far as Rooiputs in the present park.

There were also people living in the Mier Coloured Area, and particularly those 
without an adequate means of living were, to a great extent, dependent on living off the veld. Biltong hunters from elsewhere regularly raided the area. As a result the number of game showed a visible and steady decline year after year. This state of affairs did not go unobserved by some of the inhabitants, and in this regard the following persons deserve to be mentioned, namely Mr Piet (Mof) de Villiers, Inspector of Lands at Upington, also known as "King of the Kalahari", and Willie Rossouw, a local farmer, community leader and Christoffel le Riche's son-in-law.

These two men were the driving force behind the establishment of the park. Both were well known to Minister Piet Grobler, the former through his senior position as a civil servant, and the latter as a friend.

The fact that various farmer associations in the area were increasingly addressing representations to have the area between the two rivers made accessible as farming land, provided the final stimulus to set the ball rolling. As a result of the two men's discussions, Minister Grobler was invited to accompany them on a hunting expedition in the Kalahari.

Starting at Willie Rossouw's farm, Loubos, the expedition travelled along the river to the confluence, and from there up along the Nossob. Along the way the scarcity of game was pertinently brought to the Minister's attention - especially in those areas where Coloureds were living on the Botswana side. During the first night around the campfire, the usually talkative Minister Grobler was very quiet, and the two friends added fuel to the fire by stating that they might have more luck as they proceeded. On the following morning the first positive reaction came from this Member of Cabinet when he announced his intention to have the area between the two rivers and up to the SWA border proclaimed a national park to preserve it for posterity. The fact that the area was already earmarked as a Coloured area posed a problem, but the two men from the Kalahari already had a solution in mind. They suggested that the land to the south of the proposed park, including Loubos, be acquired by the Government and exchanged as compensation.

Soon afterwards talks were held with all local Coloured leaders, even some from Rehoboth, during which the object in view was put foward. Fortunately the general and unanimous support of all parties concerned was gained, especially when it was mentioned that the Kuruman Nature Reserve to the south of the park would be thrown open for Coloured habitation. This also provided refuge for the borehole guards along the Auob.

With a few exceptions, all the privately-owned farms in the area were purchased and the area was proclaimed a national park on 3 July 1931. Originally it included only the area as outlined above. In 1935 a row of farms along the southern bank of the Auob were acquired and added to the park. The latter border was not a straight line, since it followed the farm boundaries. At a later stage the boundary was straightened by means of an exchange transaction on a give-and-take basis with the authorities.

Soon after the proclamation, the first ranger, Johannes le Riche, Joseph's (Joep) elder brother, was appointed at a salary equal to R15 per month. He had one assistant, a Coloured constable called Gert. Some horses and a cart were all these two men had with which to enforce the Act on National Parks in a thirstland stretching 
over nearly 13000 square kilometres with an unfenced border of about 650 kilometres.

Johannes le Riche and his family of nine - including two pre-school children established their headquarters at Gemsbokplein along the Auob, about 30 kilometres from the confluence, where they moved into one of the "hartbeeshuisies" (wattle-and-daub huts) evacuated by the borehole guards. It must be kept in mind that at that stage, the National Parks Board of Trustees had only been in existence for five years, that it had no reserve funds, no income from the Kruger National Park as yet, and was financially completely dependent on the State - and the country was experiencing a depression.

Numerous problems were encountered - almost too many to solve. Some of the people living along the borders of the park came, plundered, and went at random; people travelling through the park along the Auob and Nossob in motor vehicles sometimes openly handled their rifles and ammunition prior to their departure, knowing that the ranger could not follow them; there was almost no water and there were still some privately-owned farms within the park.

As a result of the severe drought experienced during those years, there was no natural water in the rivers and pans. Even during years of good rainfall these water resources were merely of a temporary nature. There were sixteen boreholes and three good wells in the Auob. The borehole guards had taken along all the existing windmills when they left for the Kuruman and during its initial phase the park only had two windmills which were erected by the Board at Gemsbokpiein and Munro.

There were only four watering points in the Nossob, namely two wells in the southern part dug by the Coloureds within the first 24 kilometres, a borehole at Kij Kij with very bad tasting water, and a well operated by a hand-pump at Unie-End. There was also a well about 60 metres ( \pm 200 feet) deep, which allegedly provided about three litres per hour - too little to be of any practical value.

Twee Rivieren at the confluence, and Kij Kij about 30 kilometres north of the confluence along the Nossob, were the two most important privately-owned farms within the park. As far as Twee Rivieren was concerned, it meant that both rivers and their banks did not form part of the park for about eight kilometres from the confluence. Each farm covered an area of about 13000 hectares. Due to Minister 'Grobler, Twee Rivieren was acquired soon after the establishment of the park. By means of their recommendations a commission of the Board, under direction of the well-known Mr. Ludorf, saw to it that Kij Kij was also acquired in 1938 - at the royal sum of one shilling (10c) per morgen.

Problems with local residents - synonymous with poaching - were only solved many years later, since this involved, among other things, the fencing of the park in order to indicate legal borders, and prevent the migration of game beyond the borders of the park. This ideal situation was only achieved much later. Seven years after the establishment of the park the area to the east and along the length of the Nossob about forty kilometres into Botswana was proclaimed a reserve and it was added to the park since the National Parks Board was asked to take over the jurisdiction of the area. In the same year (11 May) the Coloureds along the river on the Botswana side ( 84 families with more than 5000 head of stock) were informed that 
they had to resettle in the area south of the park. This measure brought about much relief, since these people were, as a result of their domiciliation in the neighbouring state, almost untouchable. The day after the decision was announced to all concerned at a meeting, Joep and the then Secretary of the Board surprised a party of Coloureds who had in their possession, among other things, 56 ostrich and 60 jackal hides - the result of two months of poaching activities.

The lack of a proper vehicle caused serious problems, one of which has already been discussed. Even a routine task such as collecting post at Askham about 100 kilometres away, took one week. It took two weeks to travel to Upington from where essential provisions had to be fetched ( 800 kilometres there and back). Patrols in the park which had to take place on a regular basis, proved to be torment in this arid, hot region. The longest patrol, from headquarters (Gemsbokplein) along the Nossob to the furthest point (Unie-End) and back, was a journey of about 650 kilometres through thirstland - in one stretch of 250 kilometres no water was available at all. This situation was somewhat relieved by a donation of four camels by the S.A. Police. Although these animals provided an extremely uncomfortable means of conveyance, at least it was not necessary to take along as much water as horses would have needed.

Only in 1934 could the Board afford a vehicle, and although it was an unsuitable spokewheel jalopy which could not be used in the dune-land, it was an enginedriven vehicle. Joep had to buy it himself - the money was loaned to him and deducted from his salary each month - with interest. Due to this vehicle the blatant poaching by passers-through could be put to a stop, and it was easier to fetch provisions. The most remote corners of the park could be visited without too many sacrifices and the problem areas in the southern part of the Nossob, where the Coloureds lived, were within quick reach.

Despite the ranger's relative immobility, he caught his first poacher shortly after he had been appointed. Due to the concern shown towards nature conservation by the then magistrate of Upington, Mr Vlok, those found guilty of poaching were heavily fined. A fine of $£ 15$ (R30) for one antelope - a considerable sum of money in those days - was not uncommon. The Kalahari Gemsbok National Park was the first of the Cape parks to show an income - out of fines (Addo and Bontebok were proclaimed on the same day as Kalahari). The situation in the park, with travellers between South Africa and South West Africa being allowed to make use of the roads in the riverbeds, was totally undesired. The only way to stop these people from poaching, would have been to establish control posts at the border posts Mata Mata and Unie-End. Johannes le Riche requested this from the Board and even recruited a White man who was willing to work for $£ 6$ (R12) and a springbok and gemsbok per month. A Coloured, who was to man the post at Unie-End, was willing to work for even less. Because of the lack of money the request could not be granted, though.

In 1934 the Kalahari displayed its other climatological extreme - it rained so much that both rivers were in flood for the first time this century. Neither did it happen only once, because no sooner had the level of the water receded, than it started raining again, and the whole process was repeated. What was supposed to bring prosperity and joy to this arid land, brought adversity to the newly-estab- 
lished park and the Board. Johannes and Gert, ironically enough, both contracted malaria and died.

A few days after his brother's death, Joep le Riche was requested to take over responsibility for the park. He agreed to do so temporarily. This "temporarily" was to extend into 36 years (until 31 July 1970). He immediately appointed a new Coloured constable, Gert Mouton. Both men were single and they moved into the headquarters at Gemsbokplein.

One of the new ranger's first tasks was to fetch his new vehicle at Upington. The rivers were in flood once again, so he had to travel along the banks and it took him two days to reach Twee Rivieren. He could not cross the river, so he had to travel along the Nossob on the Botswana side to the first Coloured settlement, Leeudril, where he requisitioned a wagon and 20 donkeys, hauled the vehicle on to the wagon and crossed the Nossob through water some 1,2 metres (4 feet) deep. He returned along the bank to the confluence, and then up along the Auob to Gemsbokplein, where he arrived on the afternoon of the third day.

As a result of the floods, all the wells and boreholes silted up and had to be cleaned after the rainy season - a major task to be performed by a couple of men with only a few draught animals and no more than a single pulley and bailer.

Joep and Cillie were married in Upington on 10 July 1934, shortly after his appointment. Soon afterwards he contracted malaria, but thanks to large doses of quinine and good care, his health was soon restored.

In the spring of 1935 yet another extraordinary event took place. During the first dry thunderstorm which ushered in the new season, lightning started a fire in the Botswana part of the park and the area experienced its first veldfire in decades. Fortunately the fire was checked by the Nossob, because the few men with their primitive appliances would never have been able to extinguish it. This phenomenon repeated itself forty years later when veldfires were caused by lightning all over the park for several consecutive years during the mid-seventies. During the years in between the floods, the rainfall for the area was near to normal (approximately $150 \mathrm{~mm}$ per annum). During the years when the floods occurred, the rainfall averaged at least three times as much - just like forty years ago - and up to $550 \mathrm{~mm}$ were measured. As a result the grass cover was abnormally good and dense enough for veldfires to occur.

Apart from patrols, which had to be undertaken on a regular basis in order to combat poaching and other offences, the ranger tried to improve the water situation by building small dams in the rivers, at wells and at boreholes in which rainwater could be stored in order to improve the subterranean water. It is difficult to assess the value of these measures, however.

In 1936, during a patrol through the central block of the park, Joep encountered a group of Bushmen at Sewe Panne, as it was called then. Since it was Minister Grobler's explicit wish that the park should act as refuge for the Bushmen to save them from extinction, this group of 20 was lured closer by means of tobacco and food to put them at ease. Although communication was impossible, they were persuaded by means of gesticulation to accompany the ranger to Gemsbokplein where their needs could be provided for. 
During this period a number of meaningful things happened. Christoffel, or Stoffel, le Riche was born - the first White child to be raised in the park. The second ranger, Piet Moller, was appointed and stationed at Mata Mata. Jan Jannewarie became constable and took over responsibility for the post at Unie-End.

During 1938 another milestone was reached - the 40 kilometres wide strip along the Nossob in Botswana was proclaimed a nature reserve. Since the Nossob is the mainspring of the whole eastern part of the park, and the areas on both sides form one large ecological unit - as the migratory patterns of game in the park clearly indicate - this was certainly the most important event in the history of the park at the time. As far as nature conservation is concerned, the British colonial government conveyed total jurisdiction over the area to the National Parks Board of South Africa, and this arrangement is still valid. In the same year Joep marked the border of 270 kilometres in Botswana by means of wooden poles. Still in the same year the Board, acting on Piet Mof's advice, decided to acquire a house built of corrugated iron to replace the ranger's poor accommodation. This house was erected at the confluence of the two rivers.

Yet another commission under the direction of Mr J. F. Ludorf, Vice-President of the Board, visited the park in 1938 - just before the above-mentioned events - to advise the Board. Apart from recommending that the wattle-and-daub hut be replaced because it was altogether "unsuitable for and detrimental to human habitation", the commission suggested other drastic changes. The most important were to sink more boreholes, acquire more camels and appoint more constables. The most far-reaching suggestion, however, was to close the Nossob for traffic en route to SWA. Although this suggestion originally met with opposition, the Board eventually decided to adopt it - to the joy of the park officials - and, in doing so, yet another problem was solved.

To suggest the sinking of more boreholes was easy - provided the necessary funds were available. But to find sufficient potable water in the Nossob in particular was a different matter altogether. Thirteen holes were sunk within one year, the shallowest with a depth of 66 metres (218 feet), and the deepest with a depth of 113 metres (372 feet). Four were dry, five contained salt water and were therefore of no use, two supplied less than 700 litres per hour, and only two were reported to supply strong, potable water. A great number of holes had to be sunk before enough water was provided for the Nossob rest camp to be established. In one case a hole 372 metres (1 200 feet) deep was sunk. Drinking water was absolutely vital to the existence of the park, a fact which was accentuated by rangers and commissions alike ever since the establishment of the park. In the report filed by the Ludorf Commission it was mentioned that thousands of animals died of thirst during a prolonged drought a few years before. At the time the game migrated as far as Upington, and the Kalahari was almost depopulated. It was also mentioned that drinking water is only essential during dry hot summer months, namely from October to February. Otherwise the game obtained sufficient moisture from the vegetation, and the tsama melon in particular, provided the rainfall was enough to enable growth. Although this statement is true, permanent drinking water would have had the added advantage that the complete depopulation of the area would have been prevented. Information on the game in the Kalahari nevertheless 
clearly indicates that local migrations on a smaller scale in search of greener grazing are not influenced by the availability of permanent water. These migrations are triggered off as soon as showers fall in the area. Neither does it have any effect on the well-known en masse migrations of especially springbok, eland and red hartebeest, such as occurred in 1937, 1946, 1950 and 1954. At present the park has about 80 boreholes complete with windmills, situated mainly in the two rivers, which provide water for man and beast.

During the war (1939-1945), when all weapons were confiscated by the government in order to prevent the possibility of a rebellion and there was hardly any ammunition available for illegal weapons, poaching subsided and game numbers increased markedly. In 1941 the ranger reported a herd of eland numbering about 1000 at Kameelsleep. As a result of this increase the predator population also flourished. Since these predators have no respect for borders, they caused numerous problems, especially on the SWA side of the border. Lacking firearms, the farmers reverted to poisoning - a practice which, unfortunately, still continues.

After the war an extraordinary abundance of weapons and ammunition were in circulation, since the war surplus was made available to private individuals, and this resulted in a wave of unprecedented poaching. At first the poaching occurred only sporadically, but soon it degenerated into massacres. It will never be known how many of these poachers/butchers committed this hideous crime unobservedly. However, many of them - even friends and acquaintances of Joep le Riche ended up in court, especially after the park officials were provided with four-wheel drive vehicles. In one wave of poaching Joep in one week (1 to 7 June 1948) caught no less than 42 poachers who had killed 45 head of big game and a large number of smaller game. Initially only inhabitants of neighbouring areas - mainly Coloureds - were involved, but later Whites from far and near equipped with only the very best vehicles and weapons, started taking part in the slaughter. Although the park was being threatened from all sides, the situation was at its worst in the Botswana area. On one occasion the rangers found more than one hundred springbok carcasses from which only the stringy biltong had been removed, within a radius of 50 metres. On another occasion 23 eland carcasses were found. There are many anecdotes about the poaching and the inevitable conflict with the park officials, the Le Riche family in particular. Sometimes these encounters were serious and even dangerous, but on other occasions the situations were rather comical.

The matter took on such proportions that Joep thought it necessary to write a long letter to the District Manager at Tsabong in Botswana, who represented the highest legal authority in the south-western part of the park. Joep explained the gravity of the situation and requested his co-operation in fighting the crime. Excerpts from his letter read as follows:

"There were hardly any animals in the park when I was appointed here in 1934. No animal could be seen within the first forty miles $(64 \mathrm{~km})$ along the Auob, because the Union agricultural area had then just been enlarged. Neither were any animals observed for the first 84 miles $(136 \mathrm{~km})$ along the Nossob, because there were Coloureds living on the banks on the Bechuanaland side up to Kameelsleep. They hunted on a large scale even as far as Unie-End, and from the river into British Bechuanaland ...”. 
the following years more accommodation was added and in 1957 the main camp could house 20 individuals and Mata Mata 12.

The increase in the number of visitors is naturally not only due to the availability of accommodation, since many visitors did not stop over in the park, but through the years it became apparent that these and other available facilities did have a positive influence on the tourist industry. Unfortunately there are no statistics in the Board's official documents for the period before 1953, but since then reports on tourism were filed. The number of tourists increased from a mere 515 in 1954, 4853 in 1960/61, 11000 in 1971/72, to a record number of 14794 in 1975/76. The fuel crisis left its mark, though, because the number of tourists decreased markedly (10 716) during the following year and the totals have remained at just over 10000 (with a commercial turnover of R1 699022 in 1979/80) ever since.

Where tourist facilities are concerned, the following facts are worth mentioning:

1. The shop and flat at Twee Rivieren were commissioned in 1959.

2. Nossob rest camp was commissioned during the 1964/65 financial year (official inauguration April 1966).

3. Electricity was provided to the three camps in 1970 .

4. At present 83 visitors can be accommodated in buildings in the park.

5. There are 30 caravan stands.

6. The dune road between the Auob and Nossob was made accessible to tourists in 1966.

At present there are four officials responsible for tourism.

Where nature conservation is concerned, relatively significant, yet no dramatic progress has been made. The water supply was already discussed before as well as the problems experienced on the border. Apart from the fact that the borders were not clearly defined, especially on the Botswana and SWA sides, game continually moved out of the park and fell prey to hunters, for example approximately 1500 eland during 1958/59. Park officials had no control over the situation. Since 1956/57, when the first 30 kilometres of the border between SWA and the park north of Mata Mata were fenced off, this untenable situation gradually improved up to a point where only some species, especially predators, sporadically leave the park by digging holes underneath the fence. Before the fence could be completed,

- the whole border had to be surveyed again because all the beacons were covered with sand. (The first survey was done by the well-known J. H. Orpen in 1946.) The final survey was conducted in 1958/59, and the construction of the fence, which was done by the Parks Board in collaboration with the South West African Administration, was completed in 1966 . As was expected, the fence was considerably damaged at first, because the animals were not used to such an obstruction. Fortunately most of the animals which damaged the fences were trying to gain entrance to the park.

The fence between the park and the Coloured area was erected during 1962/63. In this case it was decided to move as many game as possible back into the park. For this reason an opening was left in the fence near Kafferspan, while the rest of the fence was completed.

Where nature conservation officials are concerned, the situation also gradually improved. Joep, the only White among a number of Coloureds, had to do all the 
work in the park for the first seventeen years. At round about 1949, a Mr Du Toit was appointed ranger at Mata Mata, but his period of office was of short duration. Piet Moller took over from him in 1949. He remained in the park long enough to make his mark. His term of service expired in 1957/58.

This started a whole new era in the park since it created the opportunity for the reinforcement and continuation of the Le Riche regime, because Stoffel was appointed in the vacant post. He was in such a hurry to accept his new responsibility at Mata Mata that he, against the will and explicit warnings of his father, left Twee Rivieren the night before by Landrover. The following morning Joep met with a complete silence when he tried to contact Stoffel by radio (which was installed in December 1956). With his warnings fresh in his mind, he set off on the road along the Auob. He did not travel far before his suspicions were confirmed. A Landrover with no lights and a broken radiator - the result of a collision with a gemsbok - and a perplexed ranger awaited him in the middle of the road. As was to be expected, he was not overly friendly when he addressed his son after a fleeting inspection of the vehicle with "What a good start!" Prior to Stoffel's appointment someone was appointed at Twee Rivieren to take care of all technical problems. He also carried the title of ranger. The well-known, almost legendary Willie Jacobs was the first person to be appointed in this position.

The Le Riche hierarchy was enforced by the appointment of Elias at Nossob in 1963. Fortunately his appointment went without a hitch. So from 1963 until Joep's retirement the park was completely in the care of the Le Riche family. Stoffel succeeded Joep as Park Warden - and Izak Meyer was appointed in his position as ranger at Mata Mata. This did not signal the end of the Le Riche era, for with Stoffel's sudden demise at a youthful age in 1980 his brother Elias succeeded him as Park Warden. Dawie de Villiers took over his position as ranger.

Although the rangers were equipped with four-wheel drive vehicles at an early stage, whicn enabled them to patrol all remote corners of the park, the lack of proper roads was the cause of many problems and wasted time.

The Divisional Council maintained the roads in the riverbeds, but was disinclined to the construction of any new roads, whether for tourist or patrol purposes. This matter only received attention when the park acquired its own road-grader in 1962. In the same year various roads were constructed, namely the dune road (Kamkwa to Kameelsleep) through the dunes (67 kilometres), a patrol road from Moravet via Seven Pans and Bayip to Unie-End (140 kilometres), a road along the fence from Unie-End to Mata Mata (110 kilometres), and a patrol road from Bayip to the windmill at Okiep (16 kilometres). The network of roads allows the field personnel to work much faster and more efficiently.

In 1954 a new dimension was added to the activities in the park. The first scientific report was compiled by the first assistant biologist in the southern national parks, Mr A. M. Brynard. He was the only research officer for these parks and resided at the Mountain Zebra National Park. As a result the Kalahari and other parks in the Cape did not receive much attention. The logical step was to obtain the aid of socalled "outsiders" to fill this void. In February 1957 a large group of scientists from the University of Pretoria, the University of the Witwatersrand, the Transvaal Museum, the Witwatersrand Medical School, the Department of Agriculture and 
the Pest Research Laboratory were accompanied to the Kalahari by the late $\mathrm{Mr}$ R. J. Labuschagne to determine research priorities. They were most probably indoctrinated and bullied into undertaking various research projects! The first project to be undertaken was a botanical survey by $\mathrm{Dr} \mathrm{O}$. Leistner, and the result was published in Koedoe No. 2 (1959). In 1960 a small laboratory was erected at Twee Rivieren with money donated by the Rembrandt organisation. After a while this structure had to be used for other purposes, but similar facilities were erected at Nossob in 1969/70.

Although a few South Africans, as well as visitors from overseas, were sporadically involved in research projects in the Kalahari, only a few persons from the University of Pretoria, namely Profs F. C. Eloff, J. du P. Bothma, J. A. J. Nel and W. van Hoven, have continued their research on mainly lion, leopard, small mammals and the rumen fauna among the herbivores. All of them were also directly or indirectly involved in a variety of other research activities in the park and have disseminated information worldwide about this area and its inhabitants.

The first research post in the park was created in 1960/61 when a technical assistant was appointed. His term of service was of short duration and not much work was done. Internal research only gained substance in 1971 with the appointment of Mr M. G. L. Mills, who had started his research project on the brown hyaena in 1969 when he was still studying. Since then he has published, among other things, a number of works on the brown and spotted hyaenas of this area. Two other officials presently in service of the Board who have been involved in scientific research in the Kalahari are Drs G. de Graaff and P. T. van der Walt. The results of their work have been published in Koedoe and elsewhere.

During March 1973 a new era dawned for research when for the first time a survey of the game in the park was done by fixed-wing aeroplane. Since then aerial surveys are conducted twice a year and as a result much more information is available on the migratory patterns of the various larger game species in the park.

Because some uncertainty exists about the permanence of the present situation according to which the Botswana area forms an integral part of the park, it was recently decided, in the light of a possible forced physical division (by means of a game fence on the border) to determine whether the movements of the Kalahari game can be manipulated by the opening and closing of watering points, because the

- normal migratory patterns will be completely upset by a fence in the Nossob. In this project, which is executed in the Auob, vegetation surveys are made regularly in order to establish whether the expected rotational grazing system (as a result of the presence or absence of herbivores) will have a positive influence on the vegetation.

We presume it is in order to state that those people responsible for the conservation and development of the park during the past thirty years, have succeeded in achieving the ideals cherished for this area by Piet de Villiers and Willie Rossouw. Not only did the diminishing and almost vanishing game stocks of the era before the proclamation return to stable, natural population levels, but during this period facilities were provided to enable the public to share in this achievement. One must express the wish that our descendants will always have the privilege to report every fifty years that the status quo for the Kalahari Gemsbok National Park is still being maintained. 